\title{
Innate immunity to Paracoccidioides brasiliensis infection
}

\author{
Vera Lúcia Garcia Calich • Tânia Alves da Costa • \\ Maíra Felonato - Celina Arruda - Simone Bernardino • \\ Flávio Vieira Loures • Laura Raquel Rios Ribeiro • \\ Rita de Cássia Valente-Ferreira $\cdot$ Adriana Pina
}

Received: 8 May 2007 / Accepted: 7 August 2007

(C) Springer Science+Business Media B.V. 2007

\begin{abstract}
Innate immunity is based in pre-existing elements of the immune system that directly interact with all types of microbes leading to their destruction or growth inhibition. Several elements of this early defense mechanism act in concert to control initial pathogen growth and have profound effect on the adaptative immune response that further develops. Although most studies in paracoccidioidomycosis have been dedicated to understand cellular and humoral immune responses, innate immunity remains poorly defined. Hence, the main purpose of this review is to present and discuss some mechanisms of innate immunity developed by resistant and susceptible mice to Paracoccidioides brasiliensis infection, trying to understand how this initial host-pathogen interface interferes with the protective or deleterious adaptative immune response that will dictate disease outcome. An analysis of some mechanisms and mediators of innate immunity such as the activation of complement proteins, the microbicidal activity of natural killer cells and phagocytes, the production of inflammatory eicosanoids, cytokines, and chemokines
\end{abstract}

V. L. G. Calich ( $₫)$. T. A. da Costa •

M. Felonato - C. Arruda - S. Bernardino .

F. V. Loures - L. R. R. Ribeiro .

R. de Cássia Valente-Ferreira · A. Pina

Departamento de Imunologia, Instituto de Ciências

Biomédicas da Universidade de São Paulo (USP),

Av. Prof. Lineu Prestes 1730, CEP 05508-900, Sao Paulo,

SP, Brazil

e-mail: vlcalich@icb.usp.br among others, is presented trying to show the important role played by innate immunity in the host response to $P$. brasiliensis infection.

Keywords Cytokines - Dendritic cells · Innate immunity $\cdot$ Macrophages ·

NK and PMN Cells .

Paracoccidioides brasiliensis infection

\section{Introduction}

Innate immunity has been defined as the first phase of immune response and is based in pre-existing elements of the immune system that directly interact with all types of microbes leading to their destruction or growth inhibition. Innate immunity, which is not clonally specific for a particular pathogen and does not generate specific memory, is mediated by physical barriers, chemical elements, and cell components of the immune system. The adaptative immunity, involving more slowly developing, long-lived, and highly antigen-specific responses are mediated by cell-mediated immunity and antibody production. Several elements of innate immunity act in concert to control initial pathogen growth and have profound effect on the adaptative immune response that further develops. Furthermore, most effector mechanisms of innate immunity are identical to those of adaptative immunity that are activated at later phases of immune response. 
Several mechanisms of innate immunity such as the activation of complement proteins, the microbicidal activity of natural killer (NK) cells and phagocytes, the production of inflammatory cytokines and chemokines among others, have been shown to play an important role in the early host response to pathogens [1]. Besides their intrinsic complexities, innate immunity mechanisms present important peculiarities which depend on the site they take place [2]. The innate immune response against Paracoccidioides brasiliensis, Coccidioides immitis, Blastomyces dermatitides, and Histoplasma capsulatum, primary fungal pathogens which infect hosts through the respiratory tract, occurs in the lungs. The lung response to infection is initiated by the secretion of several antimicrobial proteins by the pulmonary epithelium and the phagocytic activity of resident alveolar macrophages. The cell-wall-degrading enzyme lyzozyme, the iron-chelating protein lactoferrin and the membrane-permeabilizing members of the defensin, cathelicidin, and pentraxin families are the initial antimicrobial proteins secreted in the alveolar lining layer of the pulmonary epithelium. Innate immunity recognition of microorganism is mediated by germ-line encoded receptors ("pattern recognition receptors, PRR") which interact with conserved pathogen structures, the so-called "pathogen associated molecular patterns" or "PAMP" [3-5]. The initial macrophage-pathogen interaction results in internalization by the activated cell which can kill the organism through the action of reactive oxygen species and lytic enzymes or extracellular microbial containment. In addition, the secretion of chemokines and cytokines orchestrates the expression of cell adhesion and chemotactic molecules which further control the influx and activation of inflammatory cells to the site of infection [1-5].

Although most studies in human PCM have been dedicated to understand cellular and humoral immune responses, innate immunity remains poorly defined. This is easily understood when one reminds that PCM infection and disease in human beings are recognized at a later and undefined period after initial infection, making difficult to evoke the early events which resulted in controlled infection or overt disease. In this aspect, experimental models are powerful tools to study the initial events that govern hosts- $P$. brasili- ensis interactions. Thus, the main purpose of this review is to present and discuss some mechanisms of innate immunity to $P$. brasiliensis infection, trying to understand how this initial host-pathogen interface interferes with the protective or deleterious adaptative immune response that will dictate disease outcome. This review does not intend to be a comprehensive revision of the PCM literature that has been reported elsewhere [6-10], but to present a personal view, mainly based in the murine model of genetic resistance and susceptibility to $P$. brasiliensis, of how innate immunity can influence PCM severity and the adaptative immune response to this pathogen.

\section{The isogenic murine model of resistance/ susceptibility of paracoccidioidomycosis mimics the human disease}

Our laboratory established a genetically controlled murine model of paracoccidioidomycosis (PCM), which allowed us to investigate several parameters of host-parasite interactions. Most of these studies were recently reviewed [10-13] and clearly showed the diverging immune responses mounted by genetically susceptible (B10.A) and resistant (A/Sn or A/J) mice to $P$. brasiliensis infection. One important characteristic of our model is the similarity with the human disease, B10.A mice mimicking the progressive, severe forms of the disease and $\mathrm{A} / \mathrm{Sn}$ mice showing similar features of the regressive or localized forms of the infection (Fig. 1). As in the human disease, our experimental model demonstrated that resistance is associated with immune responses that favor cellular immunity and activation of phagocytes, whereas susceptibility is associated with impairment of cellular immune responses and preferential activation of B cells [10-12].

After an intra-tracheal (i.t.) infection, the susceptibility and resistance patterns observed following i.p. infection were maintained, as reflected by the high mortality rates of B10.A mice and the regressive disease developed by the A/J strain. The susceptible mice were not able to restrain the infection to the lungs and, 2 months after infection, dissemination to liver and spleen was seen, characterizing a chronic, progressive and disseminated form of the disease; in the resistant mice, on the other hand, no organ 


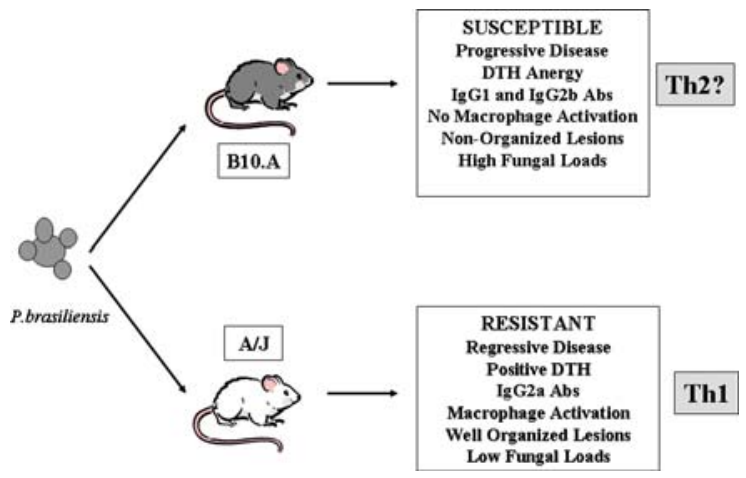

Fig. 1 Main features of the isogenic murine model of resistance and susceptibility to Paracoccidioides brasiliensis infection

dissemination occurred and a pulmonary-restricted chronic disease was observed. Unexpectedly, early in the i.t. infection (2nd and 4th weeks), A/J mice presented higher pulmonary CFU counts than B10.A mice suggesting that susceptible mice developed a more efficient innate immunity than resistant animals. The adaptative immunity of resistant mice appears to compensate their ineffective innate immunity (Fig. 2). Accordingly, from week 8 of infection onward, positive DTH responses, marked control of fungal burdens, secretion of pulmonary type 1 and type 2 cytokines and preferential production of $\operatorname{IgG} 2 \mathrm{a}$ antibodies were seen, leading to a regressive pattern of disease. On the contrary, the anergy of DTH reactions, the preferential synthesis of $\operatorname{IgG1}$ and $\operatorname{IgG} 2 \mathrm{~b}$ antibodies and the progressively increased fungal burdens of susceptible mice resulted in severe disseminated disease leading to decreased survival times [14, 15].

\section{Innate immunity}

Genetic control of susceptibility

Clinical studies suggested that susceptibility to $P$. brasiliensis is dependent on several factors, including genetic background, and host's hormonal function [4-7]. A fungal receptor for estrogen was identified and appears to block the conversion of conidia or mycelium to the infecting yeast form [16]. This finding was further explored in an animal model of infection demonstrating the enhanced resistance of female animals $[17,18]$ and may explain the unusual susceptibility of male individuals of endemic areas $[6,8,19]$.

Genetic studies performed by our group have shown the existence of an autosomal dominant gene ( $P b r$ gene), which control $P$. brasiliensis resistance [20] and appears to be similar to the Nramp gene, that control resistance to Mycobacterium sp, Leishmania $s p$, and Salmonella $s p$ infection [21]. Further studies with Nrampl congenic macrophages (B10R and B10S expressing or not the Nramp1 protein, respectively) showed that B10R macrophages, in comparison with B10S cells, expressed higher levels of mannose receptors, presented higher phagocytic ability and increased inhibitory effect on the conidia to yeast conversion [22].

\section{Complement system and chemokines}

P. brasiliensis cells are able to activate the alternative pathway of complement and yeast cells-adherent $\mathrm{C} 3 \mathrm{~b}$
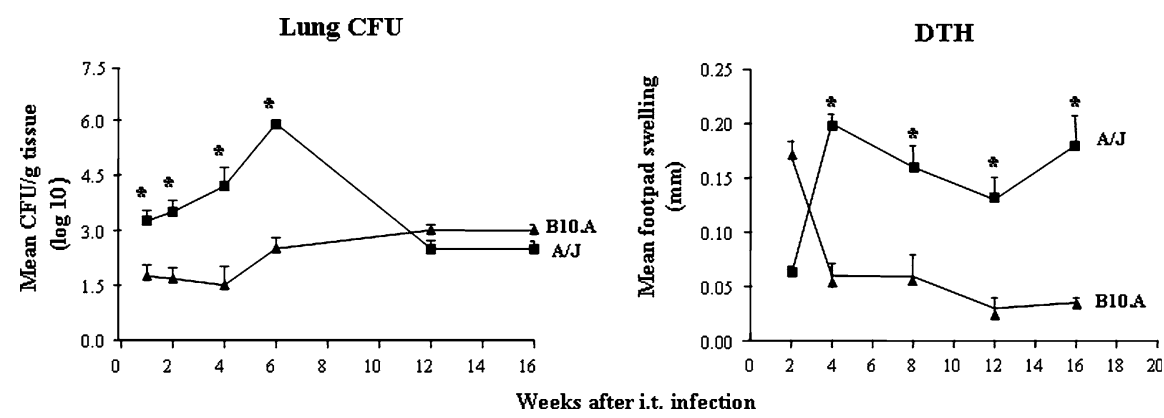

Fig. 2 At the onset of infection, susceptible (B10.A) mice show a better control of pulmonary fungal loads than resistant $(\mathrm{A} / \mathrm{J})$ mice. A/J and B10.A mice were i.t. infected with one million P. brasiliensis yeast cells. The graph on the left shows the recovery of viable fungal cell from lungs (colony forming unit counts, CFU), and the graph on the right the delayed hypersensitivity (DTH) responses measured during 16 weeks of infection 
molecules can contribute to fungi phagocytosis by macrophages [23-25]. On the other hand, chemokines which play a major role in regulating the migration of specific leukocytes subsets in both the acute and chronic inflammatory processes [26], were shown to control mononuclear cell recruitment to the lungs of P. brasiliensis-infected C57BL/6 mice [27]. Unpublished results from our laboratory suggest that increased and sustained expression of IP-10, RANTES and the chemokine receptor CXCR3 is associated with the resistant behavior of $\mathrm{A} / \mathrm{Sn}$ mice (C. Arruda and V. L. G. Calich, unpublished observations). This is in accordance with the sustained $\mathrm{T}$ cell response mounted by resistant mice at the acquired phase of the immune response $[14,15]$.

Lipid mediators (Eicosanoids) and P. brasiliensis lipids

During an inflammatory reaction, the enzymatic oxidation of aracdonic acid (AA) by cyclooxigenase produces prostaglandins, thromboxanes, and prostacyclins, whereas the 5-LO is an enzyme that catalyzes the oxidation of AA for the synthesis of leukotrienes (LT). The importance of LT as cellular activators and chemotactic factors for neutrophils and eosinophils is very well established, however, little is known about the function of these lipid mediators in the host defense against infectious agents [28, 29].

As the role of LT in pulmonary PCM was never investigated, we asked whether they would have a regulatory function in the severity of PCM of resistant (A/J) and susceptible (B10.A) mice and in the fungicidal and secretory ability of their macrophages. Our results showed that in vivo and in vitro $P$. brasiliensis infection induces LT synthesis. Compared with A/J mice, levels of pulmonary LT were higher in B10.A animals and increases in the course of infection. To evaluate the importance of LT in PCM, an inhibitor of LT synthesis (MK-0591) and an antagonist of LT receptor (montelukast) were studied in $P$. brasiliensis infection. In vitro, LT inhibitors significantly reduced the recovery of $P$. brasiliensis yeasts from normal and IFN- $\gamma$ primed macrophages. At $48 \mathrm{~h}$ of in vivo infection, montelukast treatment of B10.A mice induced diminished fungal loads, impaired influx of PMN leukocytes, and increased number of monocytes in the lungs of $P$. brasiliensis- infected mice. Furthermore, in susceptible mice montelukast treatment led to increased levels of pulmonary IL-10 concomitant with diminished amounts of IL-12, TNF- $\alpha$, and GM-CSF. In contrast, at the chronic phase of the disease, LT inhibition did not alter the fungal loads of B10.A and A/J mice. In conclusion, our results showed for the first time that LT are important mediators of the acute inflammatory reaction induced by $P$. brasiliensis infection affecting fungal recovery, cellular influx, and cytokines synthesis by susceptible mice [30, L. R. R. Ribeiro and V. L. G. Calich, unpublished observations]. Importantly, our findings with LT inhibition appear to demonstrate that the activation of innate immunity can result in increased ingestion and survival of $P$. brasiliensis yeasts which can evolve to a more severe disease.

Several lines of evidence suggest that prostaglandins production has a deleterious role for P. brasiliensis-infected hosts. In murine PCM, at early steps of infection, secretion of $\mathrm{PGE}_{2}$ was shown to have an immunossupressive activity by inhibiting IL-12 production and up-regulating IL-4 and IL-10 synthesis [31]. In addition, studies with normal and IFN- $\gamma$ activated human macrophages demonstrated that prostaglandins secretion inhibited their fungicidal ability which depends on the levels of hydrogen peroxide produced [32, 33]. Interestingly, recent studies showed that virulent and low virulence strains of $P$. brasiliensis are able to synthesize prostaglandins by a cyclooxigenase-dependent pathway and that these lipid mediators are required for $P$. brasiliensis survival [33].

Besides the importance of hosts lipid mediators such as the eicosanoids in innate immunity, other lipid components of pathogen membranes or walls have also been shown to play a role in the hostparasite interaction $[34,35]$. Studies on the influence of $P$. brasiliensis lipid fractions in the fungicidal and secretory activities of B10.A macrophages were developed in our laboratories. Although all $P$. brasiliensis lipid fractions are potent inducers of NO synthesis, they can inhibit or enhance the fungicidal ability of macrophages. The previous in vitro treatment of macrophages by F1 (phospholipids + neutral lipids) and F2 (short chain glycolipids) fractions resulted in increased phagocytic activity of cells, and recovery of higher numbers of viable yeasts from infected macrophages, despite the presence of high 
NO levels. On the other hand, fractions 3a (glycosylphosphatidylinositol-anchored glycoproteins) and F3b (long chain glycolipids) caused an opposite behavior; they inhibited the phagocytic ability of macrophages leading to decreased recovery of viable yeasts. As a whole, secretion of IL-10, IL-12, MCP-1, and GM-CSF induced by $P$. brasiliensis infection was inhibited by the previous pre-incubation with all lipid fractions [36, F. V. Loures, I. Almeida and V. L. G. Calich, unpublished data]. The different behavior of the studied lipid fractions could be attributed to the different physicochemical structures of these components which would interact with macrophages membranes through different PRR, and the subsequent balance of pro- and anti-inflammatory cytokines and chemokines secreted. Indeed, a further characterization of these lipid fractions will permit us to better understand the innate host response to $P$. brasiliensis infection.

Toll Like and other macrophage receptors

In mammalian cells, the Toll-Like Receptors (TLR) are transmembrane proteins, which interact with invariant molecular structures from pathogens (PAMP) and are involved in the activation of the innate immune system. Several typical pathogen components such as lipopolysaccharides, flagelin, peptidoglycans, DNA motifs, among others, are recognized by different TLR [37-42]. Early TLR activation results in the production of several inflammatory mediators and the final balance among proand anti-inflammatory components will regulate the type of adaptative immune response [37-42]. The TLR 4 is the key receptor that recognizes bacterial lipopolysaccharides, whereas TLR 2 is involved in the interaction with bacterial peptidoglycans and lipoproteins [38, 39]. TLR have been implicated in the resistance of mammalian hosts to several microorganisms [42-44] including fungal pathogens such as Candida albicans, Aspergillus fumigatus, and Cryptococcus neoformans [5]. Interestingly, our previous studies with $P$. brasiliensis infection showed that the LPS-resistant, TLR 4 deficient, $\mathrm{C} 3 \mathrm{H} / \mathrm{HeJ}$ strain is more resistant to i.p. infection than the congenic LPS-susceptible, TLR 4 normal, C3HeB/ FeJ strain [45]. Our recent in vitro studies with TLR 4 normal $(\mathrm{C} 3 \mathrm{HeB} / \mathrm{FeJ})$ and deficient $(\mathrm{C} 3 \mathrm{H} / \mathrm{HeJ})$ macrophages have demonstrated that this receptor interacts with $P$. brasiliensis cells resulting in macrophage activation as shown by increased synthesis of nitric oxide, IL-12, MCP-1, and enhanced phagocytic activity; this activation, however, was associated with augmented recovery of viable yeast cells from infected macrophages. In the acute phase of pulmonary infection, the presence of TLR 4 induces a more severe disease, with increased numbers of viable yeasts in the lungs associated with elevated synthesis of NO and IL-12. Moreover, even in the chronic phase, higher fungal burdens were seen in the lungs of TLR-4-normal mice, associated with increased levels of pulmonary IL-12 and serum antibodies (IgM and $\mathrm{IgG}$ ). Thus, the early macrophage activation induced by TLR 4 usage is not able to control P. brasiliensis infection [36, F. V. Loures and V. L. G. Calich, unpublished observations]. As LPS unresponsiveness of $\mathrm{C} 3 \mathrm{H} / \mathrm{HeJ}$ mice was linked to a point mutation in the TLR 4 gene, it is tempting to suggest that recognition of $P$. brasiliensis components (LPS like?) by TLR 4 has a not yet described contribution to the control of PCM. We have also preliminary in vitro and in vivo studies with TLR 2 knockout mice in a $\mathrm{C} 57 \mathrm{Bl} / 6$ background demonstrating a more severe infection in TLR-normal hosts or cells. Altogether, our findings with TLR-deficient animals are unusual since PRR are most commonly used by phagocytes to recognize molecular patterns of pathogens, and their interaction usually results in cell activation, enhanced secretion of pro-inflammatory cytokines and chemokines, and increased microbicidal activity. In our model, the increase production of nitric oxide and IL-12 by TLR-normal macrophages was not sufficient to control fungal growth and subsequent disease severity (F. V. Loures and V. L. G. Calich, unpublished results). These receptors appear to be used by $P$. brasiliensis yeast cells to gain access into macrophages and to escape from other fungicidal or fungistatic mechanisms of innate immunity.

Some reports have described the importance of mannose receptors in $P$. brasiliensis ingestion by phagocytic cells. Phagocytosis of yeasts by adherent peritoneal macrophages of susceptible and resistant mice was inhibited by gp-43, a $P$. brasiliensis glycoprotein most recognized by patients antibodies, as well as by Saccharomyces cerevisiae derived $\alpha$-mannan. Gp 43 was also shown to inhibit NO 
production and killing ability of cytokine-stimulated macrophages [46]. Immature dendritic cells of resistant mice appear to use mannose receptors to internalize $P$. brasiliensis yeasts [47]. In addition, comparative studies with Nrampl gene congenic macrophages (B10R and B10S) have demonstrated that B10R cells were better inhibitors of conidia to yeast conversion and expressed more mannose receptors than B10S macrophages, whereas both cell lines expressed similar levels of complement receptor 3 (C3R) [20]. As described below, CR3 was also shown to play an important function in $P$. brasiliensis adherence and ingestion by phagocytic cells [23, 24].

\section{Polymorphonuclear leukocytes and NK cells}

Differently from macrophages, murine PMN leukocytes are able to kill $P$. brasiliensis yeasts through the oxidative metabolism [48, 49]. In an air-pouch model of infection and compared with PMN leukocytes from susceptible mice, cells from $\mathrm{A} / \mathrm{J}$ mice presented superior fungicidal ability associated with their enhanced oxidative burst [50]. The antifungal activity of murine and human PMN leukocytes was shown to be enhanced by IFN- $\gamma$, GM-CSF, or IL- $1 \beta$, but not by TNF- $\alpha$ or IL-8 [51]. In contrast, TNF- $\alpha$ was shown to better enhance $P$. brasiliensis killing by human macrophages than IFN- $\gamma$ [52].

Comparing the early influx of inflammatory cells to the lungs of susceptible and resistant mice, Cano [53] demonstrated an equivalent mononuclear cell influx, but a more prominent migration of neutrophil and eosinophil PMN cells into the lung of susceptible mice. This early PMN influx was also seen early in the infection of BALB/c mice [54]. Furthermore, only in susceptible mice this early (24 h after infection) PMN influx affects disease outcome and acquired immunity further established. Interestingly, the more severe disease of PMNdepleted susceptible mice was associated with the increased presence of pulmonary IL-12 and IFN- $\gamma$ suggesting that the production of pro-inflammatory mediators not always leads to immunoprotection. Differently from primary infection, neutrophil depletion did not alter immunoprotection in secondary paracoccidioidomycosis. As a whole, our data showed that the genetic pattern of hosts exerts an important influence on the immunoprotective and immunoregulatory functions of neutrophils which appear to be essential in situations devoid of cellmediated immunity [55].

The role of NK cell has not been well studied in $P$. brasiliensis infection, but the few available investigations in this area suggest that this lymphocyte subpopulation has a complex function in PCM that varies according to the type of host or site where these cells were obtained. In the peripheral blood of PCM patients, NK cells were found in elevated number but they displayed low cytotoxic activity [56]. In vitro studies showed a direct inhibitory effect of murine NK cells on P. brasiliensis growth [57] and in a hamster model of infection, NK cells were shown to be activated at the first weeks of infection followed by an impairment of its activity associated with depressed cell-mediated immunity [58].

Our findings of illness exacerbation after in vivo depletion of IL-12 or IFN- $\gamma$ in euthymic and athymic BALB/c mice [59, 60] suggested that NK cells would have a protective role in pulmonary PCM. In vivo depletion of NK cells by anti-Asialo GM1 polyclonal antibody resulted in a more severe disease of both mouse strains, but the depletion effect was more pronounced in the NK-depleted athymic than euthymic mice. Anti-NK cell treatment led to increased antibody production by the former strain but did not modify the humoral immunity of euthymic animals, indicating that the isotype class switch in $\mathrm{T}$ cell deficient mice is influenced by $\mathrm{NK}$ cells cytokines. In addition, NK cells were shown to control PMN leukocytes influx to the lungs of infected mice. Hence, NK cells seem to have a protective effect in pulmonary PCM and their function appears to be more prominent in T-cell deficient than in T-cell sufficient mice $[61, \mathrm{R}$. C. Valente-Ferreira and VLG Calich, unpublished data].

Macrophages and nitric oxide

The crucial role of the mononuclear phagocytic system in the resistance to $P$. brasiliensis infection was demonstrated by the fact that reticuloendothelial system blockade, induced by colloidal carbon inoculation previous to $P$. brasiliensis infection (i.p. route), increased the severity of the disease in both resistant and susceptible animals [62]. 
The infection by $P$. brasiliensis occurs by inhalation of airborne propagules of the mycelial phase of the fungus, which reach the lungs, eventually evade the host defenses and disseminate via the bloodstream and/or lymphatics to virtually all parts of the body [4, 8, 10, 19]. Alveolar macrophages (AM) are believed to be important in the initial containment of the microorganisms through nonspecific or innate immune mechanisms. AM or dendritic cells (DC) also phagocytose particles and microbial organisms and carry them via lymphatics to regional hilar lymph nodes, where specific immune responses are believed to be generated.

$P$. brasiliensis proliferates ex vivo in a variety of mouse macrophages, including resident peritoneal alveolar and peripheral blood derived monocytes until the cells are lysed and killed by a yet unknown mechanism. However, the immunological activation of these cells efficiently inhibits fungal growth [48]. When alveolar macrophages were analyzed after pulmonary infection, absence of hydrogen peroxide production was observed with cells obtained from susceptible mice, whereas macrophages from resistant mice produced increased levels of this metabolite in the course of disease [14]. These different activities parallel the DTH anergy and the evident DTH reactivity developed by susceptible and resistant mice, respectively.

Brummer et al. [48, 63] have demonstrated that activation of mouse peritoneal macrophages by IFN- $\gamma$ enhances the fungicidal activity of these cells but fungal killing is independent of the respiratory burst. Further investigations showed the fundamental role of nitric oxide in the fungicidal ability of activated macrophages, which appear to use an iron-restriction mechanism to inhibit the transformation of ingested conidia to yeast cells $[64,65]$. We have confirmed the fundamental role of NO in the murine PCM [64]. In the course of infection, peritoneal macrophages from resistant mice secrete low levels of NO associated with high amounts of TNF- $\alpha$; the opposite was seen with glass adherent cells from susceptible mice. Interestingly, in vitro inhibition of NO production by aminoguanidine treatment of B10.A macrophages led to increased production of TNF- $\alpha$ indicating the inhibitory role of NO on cytokine secretion. More importantly, the disease of i.p. infected C57BL/6 mice genetically deficient for inducible nitric oxidesynthase (iNOS KO) and in resistant and susceptible mice in vivo treated with aminoguanidine and incapable of secreting NO, is more severe [66].

The dual role of NO in murine PCM was further confirmed in the pulmonary model of infection. Compared with wild type mice, a lower fungal load was observed at week 2, although at week 10 , increased number of fungi was detected in the lungs of mice genetically deficient of inducible NOsynthase (iNOS KO). The better control of fungal loads by iNOS KO mice at week 2 of infection appeared to be TNF- $\alpha$ mediated, since its in vivo neutralization abolished this difference [67, S. Bernardino and V. L. G. Calich, unpublished results). In agreement, Gonzales et al. [68] showed that TNF- $\alpha$ activated peritoneal macrophages, although not producing NO, were able to inhibit the transition of $P$. brasiliensis conidia to yeast cells. Interestingly, our studies also demonstrated that iNOS KO mice, despite the more intense fungal infection by week 10 of infection, developed better organized granulomas. Thus, the increased secretion of TNF- $\alpha$, the increased influx of activated $\mathrm{T}$ cells to the lungs, and the better organized lesions appear to compensate the genetic deficiency of NO. This was further confirmed by the equivalent survival times showed by iNOS KO and WT mice, despite the higher fungal loads in the former strain $[67$, S. Bernardino and V. L. G. Calich, unpublished data).

Recent studies were also performed aimed to understand the interaction between alveolar macrophages from resistant and susceptible mice and $P$. brasiliensis. Normal alveolar macrophages of B10.A mice, in vitro infected with $P$. brasiliensis yeasts, can be activated by small doses of exogenously added IFN- $\gamma$, secrete high levels of IL-12, nitric oxide and display a very efficient fungal killing activity. In contrast, macrophages from $\mathrm{A} / \mathrm{J}$ mice were poorly activated by low doses of IFN- $\gamma$, secrete low amounts of IL-12, NO and present a poor fungicidal ability concomitant with the production of high levels of active TGF- $\beta$. The fungicidal ability of B10.A macrophages was modulated by aminoguanidine, whereas TGF- $\beta$ was the main negative regulator of A/J macrophages. Thus, alveolar macrophages of susceptible mice seem to be more efficient than those of resistant mice and interaction of $P$. brasiliensis with these cells probably occurs through different macrophage receptors [69 A. Pina and V. L. G. Calich, unpublished observations]. These findings 
appear to explain the apparently discrepant result we had observed when the pulmonary model of infection was first described: at the beginning of infection higher number of viable yeast cells were recovered from lungs of resistant mice as compared with susceptible ones [14]. Furthermore, IFN- $\gamma$, the most efficient macrophage activator was found in higher levels in the lung homogenates of susceptible mice [59]. Thus, the innate immunity appears to be much more efficient in the susceptible strain than in the resistant one. This hyperactivity is concomitant with high levels of NO production that is able to restrain fungal growth but also interferes with acquired immune responses leading to a subsequent immunosuppression of T-cell mediated immunity [66, A. Pina and V. L. G. Calich, unpublished data].

\section{Dendritic cells and other APCs}

$\mathrm{T}$ cells have clonal receptors (TCR) educated to see antigen epitopes presented by major histocompatibility complex (MHC) molecules of antigen presenting cells (APC). Several cell types can exert the APC function such as macrophages, B cells and endothelial cells, but the dendritic cells (DC) are considered the "professional APC" due to their special ability to activate $\mathrm{T}$ cells. DC are derived from hematopoietic stem cells in the bone marrow and form a network of a heterogeneous cell populations. Many DC reside and traffic through nonlymphoid peripheral tissues, continuously surveying the environment for invading microorganisms [70]. During infection, DCs in the periphery are activated by interaction with microorganisms or inflammatory mediators to increase their expression of MHC and co-stimulatory molecules such as CD80, CD86, and CD40. They also modify their expression of chemokines receptors and adhesion molecules, causing migration from the periphery to the $\mathrm{T}$ cell zone of draining lymph nodes. Activated DC then display pathogen encoded antigens to naïve antigen-specific $\mathrm{T}$ cells which initiate primary $\mathrm{T}$ cell responses [71, 72]. In the course of maturation, DC are subject to profound changes. The endocytic capacity is downmodulated, while there is a marked up-regulation of MHC class II expression, from an already high constitutive level [72].

As with other infectious pathologies, some studies on the importance of different antigen presenting cells (DC, macrophages, and B cells) in the resistance to $P$. brasiliensis infection were reported. It was shown that gp43, the immunodominant antigen for humoral immunity in PCM [73], was mainly presented by macrophages and stimulated a preferential Th1 cytokine production in resistant mice. In contrast, in susceptible mice gp43 was predominantly presented by B lymphocytes and led to preferential secretion of Th2 cytokines. In addition, no differences in $\mathrm{T}$ cell reactivity of resistant and susceptible mice were detected. [74]. Another report from the same group showed that the s.c. injection of mature DC, macrophages and B cells primed naïve susceptible and resistant mice and induced $\mathrm{T}$ cell proliferation. In this study, however, macrophages and B cells from both mouse strains displayed equivalent stimulatory activity inducing a preferential secretion of IL-10 and IL-4; DC from resistant animals, however, when compared with B10.A DC, stimulated a higher production of IFN- $\gamma$, equivalent levels of IL-12 and higher expression of MHC class II and CD80 molecules. B10.A macrophages were also shown to secrete high levels of IL-6 while IL-12 was secreted in similar levels by DC of both strains. Hence, it was suggested that DC of resistant mice preferentially drive Th1 development while B cells and macrophages from both mouse strains appeared to induce the differentiation of a Th0 or Th2 phenotype [75]. Further studies with resistant [76] and susceptible mice derived DC [77] demonstrated an equivalent behavior of gp- 43 stimulated DC. Thus, gp43 treatment as well as $P$. brasiliensis infection down-regulated MHC class II, CD80, CD86, CD54, and CD40 expression as well as IL-12 and TNF- $\alpha$ secretion by LPS-treated DC. So, no major differences were reported in the activities of DC obtained from resistant and susceptible mice, unless they were previously activated by LPS. The i.v. infusion of DC previously treated with gp-43 plus LPS, but not with each of these components individually, increased pulmonary CFU counts and altered granulomas morphology of $P$. brasiliensis-infected mice [77].

We have also preliminary results comparing the behavior of DC from resistant and susceptible mice. Bone marrow derived DC were obtained and activated with LPS, $P$. brasiliensis yeast cells or a soluble whole yeast cells antigen. DC from both mouse strains exhibited MHC class II and costimulatory molecules (CD80, CD86, CD11c, 
CD40) when activated by LPS or fungal yeast cells although A/J DC presented higher CD11c and CD86 expression. Compared with A/J cells, B10.A DC secreted higher levels of IL-12, IL-10, and NO, whereas the former are more able to produce active TGF- $\beta$. DC of susceptible mice induced a high proliferative activity of $\mathrm{A} / \mathrm{J} \mathrm{T}$ cells but not of B10.A lymphocytes while A/J DC stimulated $\mathrm{T}$ cell proliferation of both mouse strains. Thus, $\mathrm{T}$ cell anergy was only detected when B10.A DC were co-cultivated with homologous lymphocytes indicating that B10.A DC does not lack the ability to properly present $P$. brasiliensis antigens and that B10.A lymphocytes are appropriately activated when $P$. brasiliensis antigens were presented by A/J DCs (A. Pina and V. L. G. Calich, unpublished results).

\section{Cytokines}

As a more detailed review on the role of cytokines in PCM was reported elsewhere [10, 13], only a brief analysis of those studies will be presented here. IFN- $\gamma$ is the most important protective cytokine to susceptible, intermediate, and resistant mice to P. brasiliensis infection [59, 78]. TNF- $\alpha$ and IL-12 are also very important protective cytokines [60, 78, 79]. IL-4 has a dual role (protective or disease promoting) in pulmonary PCM depending on the genetic pattern of the host $[80,81]$. Despite the less severe disease induced by administration of rIL-12 [79], the strong inflammatory reaction in the lungs demonstrated the harmful effect of this cytokine. IL10 appears to be one important macrophage-deactivating cytokine in pulmonary PCM, and its genetic absence appears to result in the aseptic cure of infected mice (Fig. 3) (T. A. Costa and V. L. G. Calich, unpublished results). Altogether, studies with cytokine-deficient mice showed that the Th1/Th2 paradigm can be applied to explain fungal growth (or dissemination) in liver and spleen: IL-4 and IL-10 are disease-promoting cytokines while IL-12 and IFN- $\gamma$ are protective ones. However, the control of fungal growth in the lungs is more complex and both, Th1 (e.g., IL-12) and Th2 cytokines (e.g., IL-4) can have antagonistic effects. IL-10 is a disease-promoting cytokine and appears to have a more prominent role in the control of pulmonary PCM than IL-4.
Summarizing, our studies on innate immunity to $P$. brasiliensis infection suggest that a highly efficient innate immunity can lead to severe paracoccidioidomycosis. The following findings appear to support such inference: at the onset of infection, susceptible mice display a better control of lung fungal loads; IL4 protects susceptible mice from severe infection; exogenous IL-12 leads to increased lung pathology; TLR usage leads to increased macrophage activation associated with increased fungal loads; susceptible mice secrete higher levels of LT and its inhibition results in milder pathology; PMN depletion causes more severe PCM associated with increased secretion of pro-inflammatory cytokines; early NO secretion can induce more severe infection. As a whole, it appears that "the more reactive the host innate immunity the more severe is the initial P. brasiliensis infection."

\section{The influence of innate immunity in the resistance to $P$. brasiliensis infection}

Protective immunity in paracoccidioidomycosis (PCM) is believed to be mainly mediated by cellular immunity [82]. In the human disease the Th1/Th2 dichotomy of $\mathrm{CD}^{+} \mathrm{T}$ cells appears to partially explain the behavior of PCM patients and healthy infected individuals. So, the most evident Th1 immunity is observed when lymphocytes from healthy infected subjects or cured patients are in vitro activated by gp 43 and a clear production of IL-2 and IFN- $\gamma$ is concomitant with a vigorous lymphoproliferative response [83, 84]. The acute form of the disease appears to be the Th2 pole of reactivity, where IL-4, IL-5, and IL-10 are produced and associated with low $\mathrm{T}$ cell proliferation which, however, can be reverted by in vitro treatment with rIL-12 and anti-IL-10 antibodies [85]. The severe form of the chronic disease also appears to present a Th2 pattern of reactivity. Most individuals of the chronic form of PCM, however, do not display polarized Th1/Th2 immune responses and their hyporesponsiveness appears to be not linked to imbalanced cytokine synthesis and may be due to other immunoregulatory mechanisms such as $\mathrm{T}$ cell anergy, $\mathrm{T}$ cell deletion by apoptosis or suppressive activity of natural regulatory $\mathrm{T}$ cells [10, 86-88]. Indeed, a recent paper showed a direct correlation 


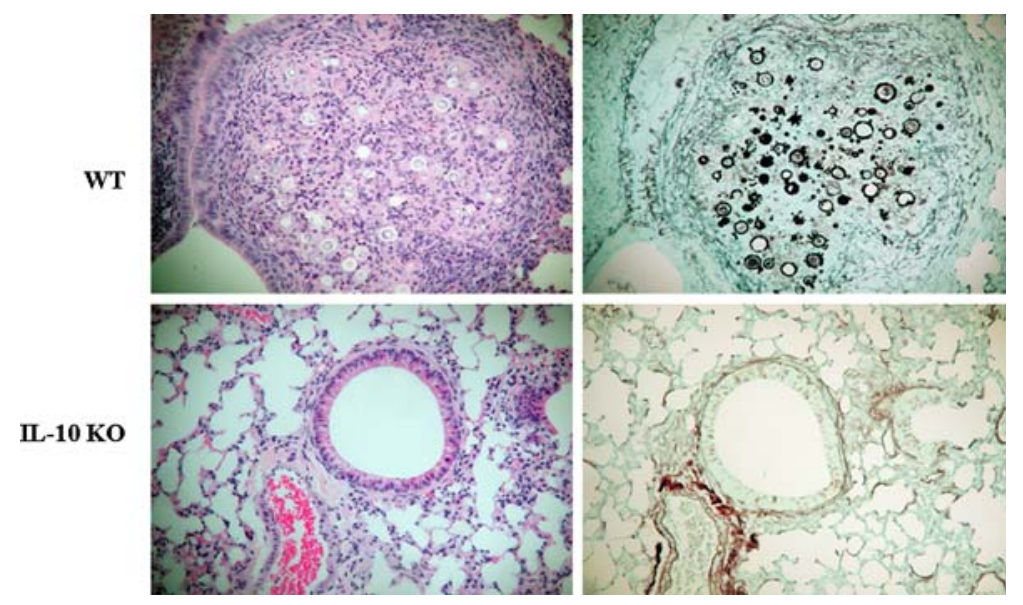

Fig. 3 Photomicrographs of pulmonary lesions developed by wild type (WT, upper micrographs) and IL-10-deficient (IL-10 $\mathrm{KO}$, lower micrographs) C57BL/6 mice at week 8 after intratracheal infection with one million fungal cells. WT mice presented extensive, fungi rich, confluent lesions, occupying

between the number of natural regulatory $\mathrm{T}$ cells in the lesions and peripheral blood and the severity of PCM [88]. In human PCM the function of $\mathrm{CD}^{+} \mathrm{T}$ cells, however, was poorly investigated.

We have some studies that characterized the function of $\mathrm{CD}^{+}$and $\mathrm{CD}^{+}$( $\mathrm{T}$ cells in the immunity developed by susceptible (B10.A), intermediate $(\mathrm{C} 57 \mathrm{Bl} / 6)$ and resistant $(\mathrm{A} / \mathrm{J})$ mice after pulmonary infection with $P$. brasiliensis yeasts. In susceptible mice, anti-CD4 treatment did not alter disease severity and cellular immunity. However, anti-CD8 treatment led to increased fungal loads and DTH reactivity indicating the antagonistic effects of $\mathrm{CD} 8 \alpha^{+}$cells. In resistant mice, besides a protective type 1 immunity mediated by $\mathrm{CD} 8 \alpha^{+} \mathrm{T}$ cells, neutralization studies revealed the concomitant presence of Th1 and Th2 cells. In addition, deficiency of whole $\mathrm{T}$ and $\mathrm{CD} 8 \alpha^{+} \mathrm{T}$ cells but not of $\mathrm{CD} 4^{+} \mathrm{T}$ or $\mathrm{B}$ cells in the $\mathrm{C} 57 \mathrm{Bl} / 6$ background led to more severe PCM and increased mortality rates. In conclusion, our studies demonstrated that in pulmonary PCM: (a) fungal loads are mainly controlled by $\mathrm{CD} 8 \alpha^{+} \mathrm{T}$ cells; (b) genetic susceptibility of hosts appears to be associated with deletion or anergy of $\mathrm{CD} 4^{+} \mathrm{T}$ cells, and finally, (c) a balanced type1/type 2 immunity is associated with genetic resistance to $P$. brasiliensis infection [10].

The concomitant analysis of innate and adaptative immunity in murine PCM lead us to propose a almost all lung parenchyma, whereas in IL-10 KO mice a diffuse inflammation, with no evident fungal cells, affected smaller areas of lungs. Left, H\&E; right, Groccot stained lesions $(100 \times)$

model on the immunopathogenesis of pulmonary paracoccidioidomycosis. Alveolar macrophages of susceptible mice are very reactive to $P$. brasiliensis components and pro-inflammatory mediators are secreted by cells involved in the innate immunity of lungs. The high production of IL-12 stimulates NK cells to secrete elevated amounts of IFN- $\gamma$ that induces the secretion of high levels of nitric oxide and other pro-inflammatory mediators by macrophages which develop a very efficient fungicidal ability. Leukotrienes and the TLR expression appear to activate macrophages and to contribute with $P$. brasiliensis endocytosis. Anti-inflammatory cytokines such as IL-10 and/or TGF- $\beta$ are secreted in low levels. Although not extensively studied, equivalent activities were found with B10.A dendritic cells. This behavior results in a very effective innate immunity and precocious control of fungal growth and would result in preferential activation of Th1 $\mathrm{CD}^{+}$cells. The excessive and continuous production of $\mathrm{NO}$, however, inhibits the initial development of $\mathrm{CD}^{+}{ }^{+} \mathrm{T}$-cell-immunity by active induction of $\mathrm{T}$ cell anergy or deletion. The elevated expression of co-stimulatory molecules (MHC class I, CD40, CD80, for example) by macrophages or DC could directly activate $\mathrm{CD} 8^{+} \mathrm{T}$ cells without the help of $\mathrm{CD}^{+} \mathrm{T}$ lymphocytes $[89,90]$. This pattern of immunity could explain the very efficient mechanism of innate immunity resulting, however, in 
B10.A Alveolar MФ

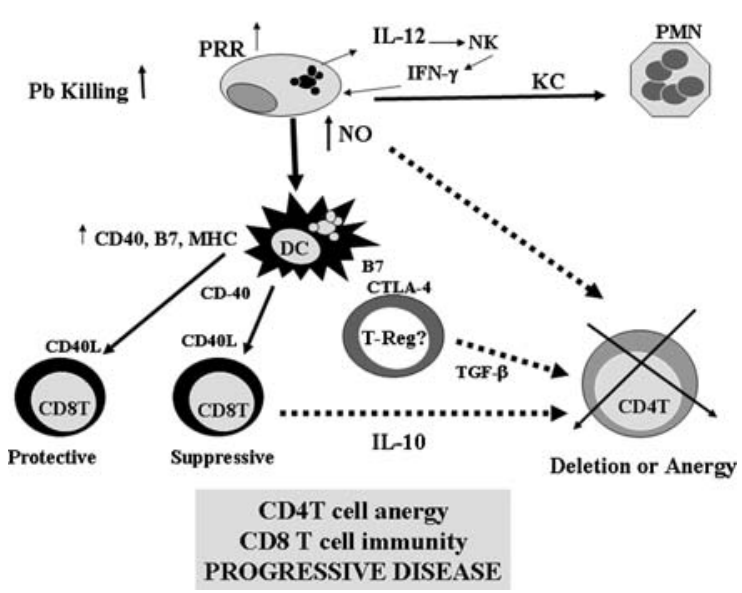

Fig. 4 Hypothesis on the innate and acquired immunological mechanisms leading to susceptibility to $P$. brasiliensis infection. At the initial stage of infection, macrophages from susceptible mice secrete high amounts of IL-12 and nitric oxide (NO) resulting in efficient fungal clearance. The same secretory pattern was seen with B10.A dendritic cells (DC). The excessive NO secretion, however, induces anergy or deletion of $\mathrm{CD}^{+} \mathrm{T}$ cells. The expression of co-stimulatory molecules such as CD40 by antigen presenting cells induces a preferential activation of $\mathrm{CD}^{+} \mathrm{T}$ cells that is not sufficient to efficiently activate macrophages and to control disease progression. (PRR, pattern recognition receptors; co-stimulatory molecules: CD40, B7, CTLA-4; MHC, major histocompatibility complex; KC, chemokine chemotactic for PMN cells; NK, natural killer cells; TGF- $\beta$, tissue growth factor beta; Treg, natural regulatory $\mathrm{CD}^{+} \mathrm{T}$ cells)

poor T-cell mediated immunity (Fig. 4). It would also explain the DTH anergy, the non-organized lesions, the high levels of antibodies, and the progressive and severe disease developed by susceptible mice.

Alveolar macrophages and DC from resistant mice respond to $P$. brasiliensis infection by secreting low amounts of IL-12, but high levels of TGF- $\beta$ and TNF$\alpha$. This results in poor NK cell activation, IFN- $\gamma$ production, $\mathrm{NO}$ secretion, and initial inefficient fungal killing. This activity characterizes the low efficient natural immunity of resistant mice. However, the production of cytokines and NO in low levels do not impair T-cell immunity. So, resistant animals slowly develop P. brasiliensis specific $\mathrm{CD}^{+}$and $\mathrm{CD}^{+} \mathrm{T}$ lymphocytes, which control fungal growth and organize lesion morphology (Fig. 5). This model does not exclude the previously proposed Th1/Th2 model of $P$. brasiliensis control. It tries, however, to put together

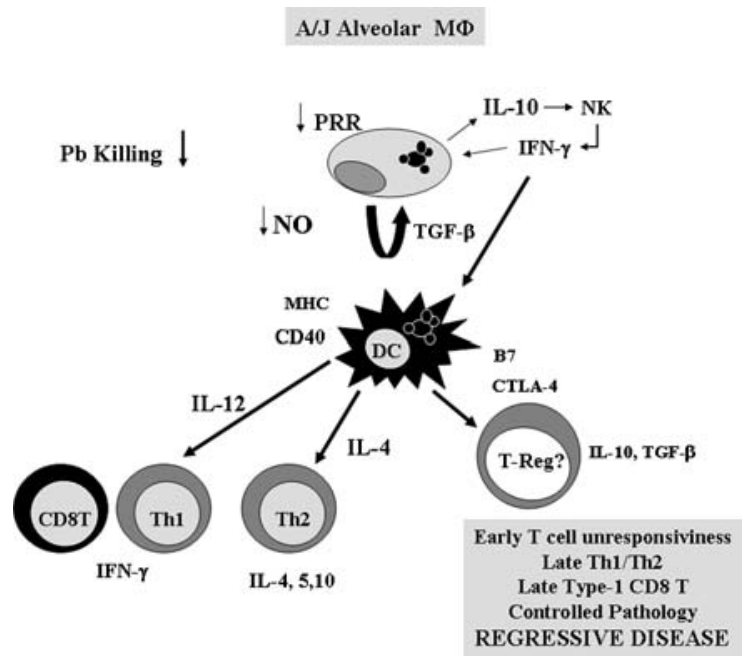

Fig. 5 Hypothesis on the innate and acquired immunological mechanisms leading to resistance to $P$. brasiliensis infection. At the innate phase of immunity, macrophages, and dendritic cells (DC) from resistant mice secrete low amounts of IL-12 associated with high levels of TGF- $\beta$ resulting in impaired nitric oxide (NO) secretion and inefficient fungal clearance. This mild pattern of activation, however, results in slow activation of Th1 and $\mathrm{Th} 2 \mathrm{CD}^{+} \mathrm{T}$ cells and type $1 \mathrm{CD}^{+} \mathrm{T}$ lymphocytes which are able to induce efficient macrophage activation, controlled inflammation, and regressive disease. (PRR, pattern recognition receptors; co-stimulatory molecules: CD40, B7, CTLA-4; MHC, major histocompatibility complex; NK, natural killer cells; TGF- $\beta$, tissue growth factor beta; Treg, natural regulatory $\mathrm{CD}^{+} \mathrm{T}$ cells)

many results obtained with studies on innate and adaptative immunity in the murine model of pulmonary infection, which eventually may contribute to enhance our knowledge on the immunopathogenesis of human paracoccidioidomycosis.

Acknowledgments This work was supported by grants from Fundação de Amparo à Pesquisa do Estado de São Paulo (FAPESP) e Conselho Nacional de Pesquisas (CNPq).

\section{References}

1. Beutler B. Innate immunity: an overview. Mol Immunol 2004;40:845-59.

2. Zaas AK, Schwartz DA. Innate immunity and the lung: defense at the interface between host and environment. Trends Cardiovasc Med 2005;15:195-202.

3. Janeway CAJR. The immune system evolved to discriminate infectious nonself from noninfectious self. Immunol Today 1992;13:11-6.

4. Janeway CAJR, Medzhitov R. Innate immune recognition. Annu Rev Immunol 2002;20:197-216. 
5. Romani L. Immunity to fungal infections. Nat Rev 2004;4:1-13.

6. Franco M, Montenegro MR, Calich VLG, Bernard G. Paracoccidioidomicose. In: Brasileiro Filho G, editor. Bogliolo patologia. Rio de Janeiro, RJ: Guanabara koogan; 2006. p. 1387-98.

7. Borges-Walmsley MI, Chen D, Shu X, Walmsley AR. The pathobiology of Paracoccidioides brasiliensis. Trends Microbiol 2002;10:80-7.

8. Brummer E, Castañeda E, Restrepo A. Paracoccidioidomycosis: an update. Clin Microbiol Rev 1993;6:89-117.

9. San-Blas G, Niño-Vega G, Iturriaga T. Paracoccidioides brasiliensis and paracoccidioidmycosis: molecular approaches to morphogenesis, diagnosis, epidemiology, taxonomy and genetics. Med Mycol 2002;40:225-42.

10. Calich VLG, Blotta MHSL. Pulmonary paracoccidioidomycosis In: Fidel PL, Huffnagle GB, editors. Fungal immunology: from an organ perspective, New York, NY: Springer; 2005. p. 201-27.

11. Calich VLG, Singer-Vermes LM, Russo M, Vaz CAC, Burger E. Immunogenetics in paracoccidioidomycosis. In: Franco M, Lacaz CS, Restrepo-Moreno A, Del Negro G, editors. Paracoccidioidomycosis, Boca Raton, Florida: CRC Press; 1994. p. 151-73.

12. Calich VLG, Vaz CAC, Burger E. Immunity to Paracoccidioides brasiliensis infection. Res Immunol 1998;149:407-16.

13. Calich VL, Kashino SS. Cytokines produced by susceptible and resistant mice in the course of Paracoccidioides brasiliensis infection. Braz J Med Biol Res 1998;31:615-23, Review.

14. Cano LE, Singer-Vermes LM, Vaz CAC, Russo M, Calich VLG. Pulmonary paracoccidioidomycosis in resistant and susceptible mice: relationship among progression of infection, bronchoalveolar cell activation, cellular immune response and specific isotype patterns. Infect Immun 1995;63:1777-83.

15. Chiarella AP. Caracterização da função das células TCD4 ${ }^{+}$ e $\mathrm{T} \mathrm{CD}^{+}$na paracoccidioidomicose pulmonar de camundongos isogênicos. Características imunopatológicas da paracoccidioidomicose experimental [M.Sc. Dissertation]. São Paulo, Instituto de Ciências Biomédicas, Universidade de São Paulo; 2002. 103 pp.

16. Loose DS, Stover EP, Restrepo A, Stevens DA, Feldman D. Estradiol binds to a receptor-like cytosol binding protein and initiates a biological response in Paracoccidioides brasiliensis. Proc Natl Acad Sci USA 1983;80:7659-63.

17. Singer-Vermes LM, Burger E, Franco MF, Bacchi MM, Mendes-Giannini MJ, Calich VL. Evaluation of the pathogenicity and immunogenicity of seven Paracoccidioides brasiliensis isolates in susceptible inbred mice. J Med Vet Mycol 1989;27:71-82.

18. Aristizabal BH, Clemons KV, Cock AM, Restrepo A, Stevens DA. Experimental Paracoccidioides brasiliensis infection in mice: influence of the hormonal status of the host on tissue responses. Med Mycol 2002;40:169-78.

19. Restrepo A, McEwen JG, Castaneda E. The habitat of Paracoccidioides brasiliensis: how far from solving the riddle? Med Mycol 2001;39:233-41.

20. Calich VLG, Burger E, Kashino SS, Fazioli RA, SingerVermes LM. Resistance to Paracoccidioides brasiliensis in mice is controlled by a single dominant autosomal gene. Infect Immun 1987;55:1919-23.

21. Forbes JR, Gross P. Divalent-metal transport by NRAMP proteins at the interface of host-pathogen interactions. Trends Microbiol 2001;9:397-403.

22. Jimenez-Mdel P, Restrepo A, Radzioch D, Cano LE, Garcia LF. Importance of complement 3 and mannose receptors in phagocytosis of Paracoccidioides brasiliensis conidia by Nramp1 congenic macrophages lines. FEMS Immunol Med Microbiol 2006;47:56-66.

23. Calich VLG, Kipnis TL, Mariano M, Fava-Netto C, Dias da Silva W. The activation of the complement system by Paracoccidioides brasiliensis in vitro. Its opsonic effect and possible significance for an in vivo model of infection. Clin Immunol Immunopathol 1979;12:20-30.

24. Munk ME, Kajdacsy-Balla A, Del Negro G, Cuce LC, Dias da Silva W. Activation of human complement system in paracoccidioidomycosis. J Med Vet Mycol 1992;30:31721.

25. Calich VLG, Burger E, Vaz CAC. PMN chemotactic factor produced by glass adherent cells in the acute inflammation caused by Paracoccidioides brasiliensis. Brit J Exp Pathol 1985;66:57-65.

26. Luster AD. Chemokines: chemotactic cytokines that mediate inflammation. New Eng J Med 1998;12:436-45.

27. Souto JT, Aliberti JC, Campanelli AP, Livonesi M, Maffei CML, Ferreira BR, et al. Chemokine production and leukocyte recruitment to the lungs of Paracoccidioides brasiliensis-infected mice is modulated by interferon- $\gamma$. Am J Pathol 2003;163:583-90.

28. Peters-Golden M, Canetti C, Mancuso P, Coffey MJ. Leukotrienes: underappreciated mediators of innate immune responses. J Immunol 2005;174:589-94.

29. Machado ER, Ueta MT, Lourenco EV, Anibal FF, Sorgi CA, Soares EG, et al. Leukotrienes play a role in the control of parasite burden in murine strongyloidiasis. J Immunol 2005;175:3892-9.

30. Ribeiro LRR. Caracterização do papel dos leucotrienos na paracoccidioidomicose (PCM) pulmonar e na atividade fungicida e secretora de macrófagos peritoneais infectados pelo Paracoccidioides brasiliensis. [MSc.Dissertation]. São Paulo, São Paulo: Universidade de São Paulo; 2005. 106 pp.

31. Michelin MA, Figueiredo F, Cunha FQ. Involvement of prostaglandins in the immunosuppression occurring during experimental infection by Paracoccidioides brasiliensis. Exp Parasitol 2002;102:170-7.

32. Soares AMVC, Calvi SA, Peracoli MT, Fernandez AC, Dias LA, Dos Anjos AR. Modulatory effect of prostaglandins on human monocyte activation for killing of highand low-virulence strains of Paracoccidioides brasiliensis. Immunology 2001;102:480-5.

33. Bordon AP, Dias-Melicio LA, Acorci MJ, Calvi SA, Serrão Peraçoli MT, Soares AMVC. Prostaglandin E(2) inhibits Paracoccidioides brasiliensis killing by human monocytes. Microbes Infect 2007;9(6):744-7.

34. Almeida IC, Camargo MM, Procopio DO, Silva LS, Mehlert A, Travassos LR, et al. Highly purified glycosylphosphatidylinositols from Trypanosoma cruzi are potent proinflammatory agents. EMBO J 2000;19:147685. 
35. Proudfoot L, O’Donnell CA, Liew FY. Glycoinositolphospholipids of Leishmania major inhibit nitric oxide synthesis and reduce leishmanicidal activity in murine macrophages. Eur J Immunol 1995;25:745-50.

36. Loures FV. Caracterização da função dos lipídios do Paracoccidioides brasiliensis e do receptor TLR4 na interação fungo-hospedeiro (M.Sc. Dissertation). São Paulo, Instituto de Ciências Biomédicas, Universidade de São Paulo; 2007. 116 pp.

37. Yang RB, Mark MR, Gray A, Huang A, Xie NH, Zhang M, et al. Toll-like receptor-2 mediates lipopolysaccharideinduced cellular signaling. Nature 1998;395:284-8.

38. Kirschning CJ, Wesche H, Ayres TM, Rothe M. Human Toll-like receptor 2 confers responsiveness to bacterial lipopolysaccharide. J Exp Med 1998;188:2091-7.

39. Chow JC, Young DW, Golenbock DT, Christ W J, Gusovsky F. Toll-like receptor-4 mediates lipopolysaccharide-induced signal transduction. J Biol Chem 1999; 274:10689-92.

40. Takeda K, Kaisho T, Akira S. Toll-like receptors. Annu Rev Immunol 2003;21:335-76.

41. Kopp EB, Medzhitov R. The Toll-like receptors family and control of innate immunity. Curr Opin Immunol 1999; 168:2433-40.

42. Takeuchi O, Hoshino K, Kawai T, Sanjo H, Takada H. Differential roles of TLR2 and TLR4 in recognition of gram-negative and gram-positive bacterial cell wall components. Immunity 1999;11:443-51.

43. Akira S. Mammalian Toll-like receptors. Curr Opin Immunol 2003;15:5-11.

44. Aderem A, Ulevitch RJ. Toll-like receptors in the induction of the innate immune response. Nature 2000;406:7827.

45. Calich VLG, Singer-Vermes LM, Burger E. Susceptibility and resistance of inbred mice to Paracoccidioides brasiliensis. Brit J Exp Path 1985;66:585-94.

46. Popi AF, Lopes JD, Mariano M. GP43 from Paracoccidioides brasiliensis inhibits macrophage functions. An evasion mechanism of the fungus. Cell Immunol 2002;218: 87-94.

47. Ferreira KS, Lopes JD, Almeida SR. Down-regulation of dendritic cell activation induced by Paracoccidioides brasiliensis. Immunol Lett 2004;94:107-14.

48. Brummer E. Interaction of Paracoccidioides brasiliensis with host defense cells. In: Franco M, Lacaz CS, Restrepo A, Del Negro G, editors. Paracoccidioidomycosis. Boca Raton, Florida: CRC Press; 1994. p. 213-24.

49. McEwen JG, Brummer E, Stevens DA, Restrepo A. Effect of murine polymorphonuclear leukocytes on the yeast form of Paracoccidioides brasiliensis. Am J Trop Med Hyg 1987;36:603-8.

50. Meloni-Bruneri LH, Campa A, Abdalla DSP, Calich VLG, Burger E. Neutrophils from air-pouches of resistant mice to Paracoccidioides brasiliensis infection are more activated and efficient in killing the fungi than those of susceptible ones. J Leuk Biol 1996;59:526-33.

51. Kurita N, Oarada M, Miyaji M, Ito E. Effect of cytokines on antifungal activity of human polymorphonuclear leukocytes against yeast cells of Paracoccidioides brasiliensis. Med Mycol 2000;38:177-82.
52. Soares AM, Calvi SA, Peraçoli MT, Fernandez AC, Dias LA, Dos Anjos AR. Modulatory effect of prostaglandins on human monocyte activation for killing of high- and lowvirulence strains of Paracoccidioides brasiliensis. Immunology 2001;102:480-5.

53. Cano LER, Paracoccidioidomicose pulmonar experimental. Caracterização do modelo de infecção intratraqueal em camundongos resistentes e susceptíveis; participação do IFN- $\gamma$, das células TCD4 ${ }^{+}$e $\mathrm{CD} 8^{+}$na resistência ao fungo. (Ph.D. Thesis). São Paulo, Instituto de Ciências Biomédicas, Universidade de São Paulo; 2007. 191 pp.

54. Gonzalez A, Sahaza JH, Ortiz BL, Restrepo A, Cano LE. Production of pro-inflammatory cytokines during the early stages of experimental Paracoccidioides brasiliensis infection. Med Mycol 2003;41:391-9.

55. Pina A, Saldiva PH, Restrepo LE, Calich VL. Neutrophil role in pulmonary paracoccidioidomycosis depends on the resistance pattern of hosts. J Leukoc Biol 2006;79:1202-13.

56. Peraçoli MT, Soares AM, Mendes RP, Marques SA, Pereira PC, Reskallah-Iwasso MT. Studies of natural killer cells in patients with paracoccidioidomycosis. $\mathrm{J}$ Med Vet Mycol 1991;29:373-80.

57. Jimenez BE, Murphy JW. In vitro effects of natural killer cells against Paracoccidioides brasiliensis. Infec Immun 1984;46:552-8.

58. Peraçoli MT, Fortes MR, Da Silva MF, Montenegro MR. Natural killer cell activity in experimental paracoccidioidomycosis of the Syrian hamster. Rev Inst Med Trop S Paulo 1995;37:129-36.

59. Cano LE, Kashino SS, Arruda C, André D, Xidieh CF, Singer-Vermes LM, et al. Protective role of interferongamma in experimental pulmonary paracoccidioidomycosis. Infec Immun 1998;66:800-6.

60. Deepe GS, Romani L, Calich VLG, Huffnagle G, Arruda C, Molinari-Madlum EEIW, et al. Knockout mice as experimental models of virulence. Med Mycol 2000;38:87-98.

61. Valente-Ferreira RC. Caracterização da importância do IFN- $\gamma$, da IL-12, dos leucócitos PMN e das células NK na imunidade natural ao $P$. brasiliensis utilizando hospedeiros normais e deficientes de células T. [Ph.D. Thesis]. São Paulo, São Paulo: Universidade de São Paulo; 2005. 172 pp.

62. Kashino SS, Fazioli RA, Moscardi-Bacchi M, Franco M, Singer-Vermes LM, Burger E, et al. Effect of macrophage blokade on the resistance mechanisms of inbred mice to Paracoccidioides brasiliensis infection. Mycopathology 1995;130:131-40.

63. Brummer E, Hanson LH, Stevens DA. Gamma-interferon activation of macrophages for killing of Paracoccidioides brasiliensis: evidence for non-oxidative mechanisms. Intern J Immunopharmac 1998;10:945-52.

64. Gonzalez A, de Gregori W, Velez D, Restrepo A, Cano LE. Nitric oxide participation in the fungicidal mechanism of interferon-gamma activated murine macrophages against Paracoccidioides brasiliensis. Infect Immun 2000;68: 2546-52.

65. Cano LE, Gómez B, Brummer E, Restrepo A, Stevens DA. Inhibitory effect of deferoxamine or macrophage activation on transformation of Paracoccidioides brasiliensis conidia 
by ingested macrophages: reversal by holotransferin. Infec Immun 1994;62:1494-6.

66. Nascimento FR, Calich VLG, Rodriguez D, Russo M. Dual role for nitric oxide in paracoccidioidomycosis: essential for resistance, but overproduction associated with susceptibility. J Immunol 2002;168:4593-600.

67. Bernardino S. Paracoccidioidomicose pulmonar em camundongos geneticamente deficientes da enzima óxido nítrico sintase-induzida (iNOS). [M.Sc.Dissertation]. São Paulo, São Paulo, Universidade de São Paulo; 2006. 82 pp.

68. Gonzalez A, Aristizabal BH, Gomez EC, Restrepo A, Cano LE. Short report: inhibition by tumor necrosis factor-alphaactivated macrophages of the transition of Paracoccidioides brasiliensis conidia to yeast cells through a mechanism independent of nitric oxide. Am J Trop Med Hyg 2004;71:828-30.

69. Pina A. Atividade fungicida e secretora de macrófagos alveolares de camundongos susceptíveis e resistentes infectados pelo P. brasiliensis. [Ph.D. Thesis]. São Paulo, São Paulo, Universidade de São Paulo; 2005. 118 pp.

70. Banchereau J, Steinman RM. Dendritic cells and the control of immunity. Nature 1998;392:245-52.

71. Sallusto F, Palermo B, Lenig D, Miettinen M, Matikainen S, Julkunen I, et al. Distinct patterns and kinetics of chemokine production regulate dendritic cell function. Eur J Immunol 1999;29:1617-25.

72. Banchereau J, Briere F, Caux C, Davoust J, Lebecque S, Liu YJ, et al. Immunobiology of dendritic cells. Annu Rev Immunol 2000;18:767-811.

73. Puccia R, Schenkman S, Gorin PAJ, Travassos LR. Exocellular components of Paracoccidioides brasiliensis: identification of a specific antigen. Infect Immun 1986;53:199-207.

74. Almeida SR, Moraes JZ, Camargo ZP, Gesztesi JL, Mariano M, Lopes JD. Pattern of immune response to gp43 from Paracoccidioides brasiliensis in susceptible and resistant mice is influenced by antigen-presenting cells. Cell Immunol 1998;190:68-76.

75. Ferreira KS, Lopes JD, Almeida SR. Regulation of T helper cell differentiation in vivo by GP43 from Paracoccidioides brasiliensis provided by different antigenpresenting cells. Scand J Immunol 2003;58:290-7.

76. Ferreira KS, Lopes JD, Almeida SR. Down-regulation of dendritic cell activation induced by Paracoccidioides brasiliensis. Immunol Lett 2004;94:107-14.

77. Ferreira KS, Almeida SR. Immunization of susceptible mice with gp43-pulsed dendritic cells induces an increase of pulmonary Paracoccidioidomycosis. Immunol Lett 2006;103:121-6.

78. Souto JT, Aliberti JC, Campanelli APM, Livonesi CML, Ferreira MBR, Travassos LR, et al. Chemokine production and leukocyte recruitment to the lungs of Paracoccidioides brasiliensis-infected mice is modulated by interferon- $\gamma$. Am J Pathol 2003;163:583-90.

79. Arruda C, Franco MF, Kashino SS, Nascimento FRF, Fazioli RA, Vaz CAC, et al. IL-12 protects mice against disseminated infection caused by Paracoccidioides brasiliensis but enhances pulmonary inflammation. Clin Immunol 2002;103:185-95.

80. Pina A, Valente-Ferreira RC, Molinari-Madlum EE, Vaz CA, Keller AC, Calich VLG. Absence of interleukin-4 determines less severe pulmonary paracoccidioidomycosis associated with impaired Th2 response. Infect Immun 2004;72:2369-78.

81. Arruda C, Valente-Ferreira RC, Pina A, Kashino SS, Fazioli RA, Vaz CAC, et al. Dual role of interleukin-4 (IL4) in pulmonary paracoccidioidomycosis: endogenous IL-4 can induce protection or exacerbation of disease depending on the host genetic pattern. Infect Immun 2004;72:393240.

82. Musatti CC, Peraçoli MTS, Soares AMVC, ReskallahIwasso MT. Cell-mediated immunity in patients with paracoccidioidomycosis. In: Franco M, Lacaz CS, Restrepo A, Del Negro G, editors. Paracoccidioidomycosis. Bocca Raton, Florida: CRC Press; 2004. p. 175-86.

83. Mamoni RLR, Nouer AMS, Oliveira SA, Musatti CC, Rossi CL, Camargo ZP, et al. Enhanced production of specific IgG4, IgA and TGF- $\beta$ in sera from patients with the juvenile form of paracoccidioidomycosis. Med Mycol 2002;40:1-7.

84. Benard G, Romano CC, Cacere CR, Juvenale M, MendesGiannini MJ, Duarte AJ. Imbalance of IL-2, IFN-gamma and IL-10 secretion in the immunosuppression associated with human paracoccidioidomycosis. Cytokine 2001;13:248-52.

85. Romano CC, Mendes-Giannini MJ, Duarte AJ, Benard G. The role of interleukin-10 in the differential expression of interleukin-12p70 and its beta 2 receptor on patients with active or treated paracoccidioidomycosis and healthy infected subjects. Clin Immunol 2005;114:86-94.

86. Cacere CR, Romano CC, Mendes Giannini MJ, Duarte AJ, Benard G. The role of apoptosis in the antigen-specific $\mathrm{T}$ cell hyporesponsiveness of Paracoccidioidomycosis patients. Clin Immunol 2002;105:215-22.

87. Campanelli AP, Martins GA, Souto JT, Pereira MS, Livonesi MC, Martinez R, et al. Fas-Fas ligand (CD95CD95L) and cytotoxic $\mathrm{T}$ lymphocyte antigen-4 engagement mediate $\mathrm{T}$ cell unresponsivess in patients with paracoccidioidomycosis. J Infect Dis 2003;187:1496-505.

88. Cavassani KA, Campanelli AP, Moreira AP, Vancin JO, Mamede RC, Martinez R, et al. Systemic and local characterization of regulatory $\mathrm{T}$ cells in a chronic fungal infection in humans. J Immunol 2006;177:5811-8.

89. Albert ML, Sauter B, Bhardwaj N. Dendritic cells acquire antigen from apoptotic cells and induce class I-restricted CTLs. Nature 1998;392:86-9.

90. Ridge JP, Di Rosa F, Matzinger P. A conditioned dendritic cell can be a temporal bridge between a $\mathrm{CD} 4^{+} \mathrm{T}$-helper and a T-killer cell. Nature 1998;393:474-8. 